\title{
Cooling ventilation at farrowing for sows from first to third parturition
}

\author{
Pedro Henrique Watanabe, Tatianne Alexandre Azevedo, \\ Margarita Augusto do Nascimento Silva, Nathalia Martins Oliveira, Thalles Ribeiro Gomes, \\ Tiago Silva Andrade, José Antônio Delfino Barbosa Filho
}

\begin{abstract}
This study aimed to evaluate the thermal comfort considering natural and cooling ventilation on the performance, physiological parameters and thermal comfort indices for sows from first to third parturition. A total of 30 sows from commercial lineage (genetic base Landrace $x$ Large White) initially weighing $252.3 \pm 5.7,280.8 \pm 9.5$ and $324.5 \pm 4.8 \mathrm{~kg}$ at first, second and third parturition, respectively, were distributed in a $3 \times 2$ factorial arrangement, considering the three parturition orders and the two ventilation methods, with five replicas per treatment. The effect of ventilation methods and times of the day on relative humidity, radiant thermal load, temperature and humidity index and black globe humidity index. There was an interaction among ventilation methods and parturition order for sow weight at weaning and daily feed intake. Regarding the females physiological parameters, with the exception of rectal temperature, there was an interaction between ventilation methods and times of the day. The thermal conditioning using cooling ventilation provides better values for thermal comfort indexes of the sows and promotes an increase in feed intake, mainly in gilts.
\end{abstract}

Keywords: Adiabatic, Lactation, Pigs, Thermal comfort

\section{Introduction}

The viability of intensive swine production is related to the efficiency in the productive and reproductive development of the matrices. For that reason, the selection of sows with greater milk yield capacity, associated to a high nutritional demand in lactation is wanted. During this phase, the energetical needs might be compromised when factors related to the sow, to the environment or to the diet are affecting the voluntary intake (Mellagi et al., 2010), making them more vulnerable to drastic changes in temperature and thermal stress (Martins et al., 2008a), resulting in the reduction of the reproductive rates.
Regarding the factors related to the environment, a dichotomic situation is observed in the nursery phase, where there is the need of providing two distinct microenvironments, so that matrices and piglets may manifest their productive potential. Matrices kept in environments with temperatures over the superior critical temperature might present a decrease in productivity, due to a greater energy demand to trigger thermolysis processes, to the detriment of the utilization for milk production (Rozeboom et al., 2000).

An intake reduction is also observed in sows which are subject to environmental stress through temperature increase, considering 
also that the age at farrowing is a variable of greater attention in primiparous sows, since they present a higher sensibility to increased environmental temperature compared to multiparous sows (Martins et al., 2008c). However, both categories in environments with increased temperature tend to direct energy to trigger thermoregulation mechanisms, like the elevation of respiratory frequency, altering the intake behavior (Renaudeau et al., 2003), reducing the intake mainly during the day (Gourdine et al., 2006), which might result in a compromise in the subsequent estrus (Renaudeau et al., 2003). Another factor to consider is related to the behavior alterations of the matrices subjected to thermal stress, being common to observe a lower number of daily sucklings, thus entailing a reduction in litter size and weight (Spencer et al., 2003).

Aiming to reduce the effects of high temperatures, there is a search for alternatives to mitigate the effects of thermal stress over the matrices development, through environmental modifications which might favor the development of the animals. Among the methods of environment climatization for lactating sows, the localized cooling presents the advantage of reducing air temperature through isenthalpic process, using the cession of sensible heath of the air in contact with the liquid surface (Tolon \& Nääs, 2005), triggering the mechanism of thermal change through convection. The efficacy of this ventilation method can be variable in function of the environmental conditions, as well as in function of the parturition order of the sows (Romanini et al., 2008; Barbari \& Conti, 2009).

With the exposed, the aim of this work was to evaluate the thermal comfort through natural and cooling ventilation over development, physiological parameters and thermal comfort indexes of lactating sows from first to third parturition.

\section{Material and Methods}

The experiment was performed in a piglet farm, located in the municipality of MaranguapeCE. 30 sows of the commercial lineage (Topigs ${ }^{\circledR}$ Landrace $x$ Large White) of first, second and third parturition were utilized, with an average weight of $252,3 \pm 5,7 \mathrm{~kg}, 280,8 \pm 9,5 \mathrm{~kg}$ and $324,5 \pm 4,8 \mathrm{~kg}$, respectively.

The females from first to third parturition order were distributed into two environments, with natural and localized cooling ventilation. The matrices were kept in the nursery shed of the commercial farm, masonry-built, in east-west orientation, with dimensions of $10 \mathrm{~m}$ length, $80 \mathrm{~m}$ width and 3,5m double-height ceiling, covered with clay roof tiles provided with a ridge vent and open laterals with a wall $0,8 \mathrm{~m}$ high. The facilities had lateral polypropylene curtains, which were opened at 07h30min and closed at 18h00. The sows' individual cages had a partially slatted floor with a conventional masonry feeder and automatic nipple drinker.

For the animals kept in the environment with localized cooling ventilation, an adiabatic air conditioner equipment was utilized, which performed a process of air cooling through the principle of the evaporative adiabatic cooling. The equipment was composed by hive-type adiabatic filter plates, with a broad humid surface, were the washings and the removal of sensible heath were performed. The air escape was directed to the upper part of the matrices head, thus providing a direct cooler air to the animals, with a speed of $10 \mathrm{~m} / \mathrm{s}$. This equipment was daily switched on from $06 \mathrm{~h} 30$ to $17 \mathrm{~h} 30$. The natural ventilation treatment was not provided of any cooling equipment, only the opening of the shed lateral curtains.

During the 21 experimental days, the data were collected at 07h00, 09h30min, 12h00, $14 \mathrm{~h} 30 \mathrm{~min}$ and $17 \mathrm{~h} 00$, regarding the physiological parameters of the sows as to respiratory rate, rectal temperature and superficial temperature of the skin at ham and withers. At the same times the data regarding dry-bulb temperatures, air relative humidity, black globe and wind speed were obtained.

Rectal temperature was obtained utilizing a veterinary thermometer $\left( \pm 0,1^{\circ} \mathrm{C}\right)$, measured during 3 minutes (Mueller et al., 2012). The respiratory rate was obtained through observation and counting of flank movements during 15 seconds, performing the correction to one minute. (Martins et al., 2008c). For the surface temperature, an infrared thermometer was also 
utilized, with digital reading from $-32^{\circ} \mathrm{C}$ to $+380^{\circ} \mathrm{C}$ and resolution of $0,1^{\circ} \mathrm{C}$, directed to the withers at a distance of approximately $50 \mathrm{~cm}$.

For the obtaining of the climatological data, two black globe thermometers were installed in the central part of the room, at the height of the sows' withers, one in each row of farrowing cells. Beside these, two $\mathrm{HOBO}^{\circledR}$ data loggers were installed, with reading range from $-20^{\circ} \mathrm{C}$ to $70^{\circ} \mathrm{C}$ for temperature and from $25 \%$ to $95 \%$ for humidity and resolution of $0,1^{\circ} \mathrm{C}$ and $0,07 \%$ for the respective variables. Furthermore, wind flow velocity was obtained through a digital anemometer with a reading range from 0,3 to $30 \mathrm{~m} / \mathrm{s}$, perpendicularly to the incidence of wind direction produced by the localized ventilation equipment. The climatological data were utilized for the calculations of the radiant thermal load (RTL) according to Esmay (1982), Black Globe Temperature and Humidity Index (BGHI), Temperature-Humidity Index (THI - Buffington et al.,1981) and enthalpy (Albright, 1990).

The sows were fed with a specific ration for this lactation phase, according to the energetical and nutritional recommendations of the lineage, being the rations moistened in the proportion 1:1 (weight : weight) at the providing moment, at the times of $06 \mathrm{~h} 00$ and 10h00. The daily ration consumption of the sows was determined from the second day after parturition until weaning, daily weighing the amount of delivered ration and its remainings. The water was freely provided during the whole experimental period. The providing of pre-initial pelletized ration to the piglets, based in corn and soybean bran, had its start in the seventh day of life of the animals. The daily ration consumption by the piglets was also measured.

The proximal weight (weight, in $\mathrm{kg}$ ) of the sows was individually obtained at 21 days after parturition with the aid of a body weighing tape for swines, based on the thoracic perimeter (TP, in $\mathrm{m}$ ) and length ( $\mathrm{L}$, in $\mathrm{m}$ ) of the sow, obtained through the equation: Weight $=T^{2} \times L \times 69,3$. The litters of each matrix were also weighed at birth and at 7, 14 and 21 days with the aid of a digital scale. The estimated milk yield by the sows was estimated through the equation utilized by Martins et al. (2007), considering the weight gain of the piglets during the 21 days and the final weight of the litter. At 21 days after parturition the sows were weighed and the weaning of the piglets was performed. The interval weaningestrus was measured according to the number of days between the weaning and a new confirmed gestation.

The experimental delimitation was completely random, in a factorial scheme of $3 \times 2$, considering the three parturition orders and the ventilation methods, totalizing five repetitions per treatment. The variance analysis of the data was performed according to the proceeding PROC GLM of the statistical software SAS (9.2). The interactions among main factors were evaluated by the $\mathrm{F}$ test $(5 \%)$ and, when significative, the effects of the main factors were studied within each level of another factor, separately, through Tukey's test (5\%).

\section{Results and Discussion}

According to the temperature averages, relative humidities $(\mathrm{RH})$, radiant thermal load (RTL), temperature-humidity indices (THI), black globe temperature and humidity indices (BGHI) and the enthalpy of the environments with natural or cooled ventilation, in function of the times during the experimental period (Table 1), the effect of the ventilation methods and times of the day over the air relative humidity and radiant thermal load on thermal comfort indices was observed, excepting air temperature, verifying only the effect on different times. Regarding wind flow velocity, an air velocity of $10 \mathrm{~m} / \mathrm{s}$ was observed for the cooled ventilation system, and absence of wind in the evaluated times.

According to Bortolozzo et al., (2011) the range of thermal comfort for lactating sows spans from $16^{\circ} \mathrm{C}$ to $22^{\circ} \mathrm{C}$, being possible to infer, through the registered temperatures in the experimental period, that the matrices were kept in environments with temperatures over the superior critical temperature. The similarity of air temperature in the environments with natural and cooled ventilation is due to the fact that the directed cooling system does not interfere in the environment temperature, through its action exclusively over sensible thermolysis only in the directed spot. 
Table 1. Air temperature, relative humidity, radiant thermal load (RTL), Temperature-Humidity Index (THI), Black globe temperature and humidity index (BHGI) and enthalpy of the environments with natural or cooled ventilation, in function of the times of the day

\begin{tabular}{|c|c|c|c|c|c|c|}
\hline \multirow[b]{2}{*}{ Time } & \multicolumn{2}{|c|}{ Air temperature, $\left({ }^{\circ} \mathrm{C}\right)$} & \multicolumn{2}{|c|}{ Relative humidity, $\%$} & \multicolumn{2}{|c|}{$\mathrm{RTL}, \mathrm{W} / \mathrm{m}^{2}$} \\
\hline & $\begin{array}{c}\text { Cooled } \\
\text { ventilation }\end{array}$ & $\begin{array}{c}\text { Natural } \\
\text { ventilation }\end{array}$ & $\begin{array}{l}\text { Cooled } \\
\text { ventilation }\end{array}$ & $\begin{array}{c}\text { Natural } \\
\text { ventilation }\end{array}$ & $\begin{array}{c}\text { Cooled } \\
\text { ventilation }\end{array}$ & $\begin{array}{c}\text { Natural } \\
\text { ventilation }\end{array}$ \\
\hline 07h00 & $25,82 a A$ & $26,26 a A$ & $65,89 \mathrm{dA}$ & $65,58 \mathrm{dA}$ & $458,65 a \mathrm{~A}$ & $488,02 a B$ \\
\hline 09h30 & $28,49 \mathrm{bA}$ & $28,78 \mathrm{bA}$ & $54,46 \mathrm{CA}$ & $55,01 \mathrm{bA}$ & $471,22 \mathrm{aA}$ & $482,66 \mathrm{aB}$ \\
\hline $12 \mathrm{~h} 00$ & $31,32 \mathrm{cA}$ & $31,07 \mathrm{dA}$ & $43,91 \mathrm{aA}$ & $47,99 \mathrm{aB}$ & $486,94 \mathrm{dA}$ & $498,93 \mathrm{CB}$ \\
\hline $14 \mathrm{~h} 30$ & $31,63 \mathrm{dA}$ & $31,00 \mathrm{dA}$ & $47,52 \mathrm{bA}$ & $51,53 \mathrm{CB}$ & $479,74 \mathrm{CA}$ & $494,16 \mathrm{bB}$ \\
\hline $17 \mathrm{~h} 00$ & $28,71 \mathrm{bA}$ & $28,36 \mathrm{cA}$ & $58,65 \mathrm{cA}$ & $60,48 \mathrm{bB}$ & $458,53 \mathrm{bA}$ & $459,86 \mathrm{~dB}$ \\
\hline Média土EPM' & $29,19 \pm 0,61$ & $29,09 \pm 0,52$ & $54,09 \pm 2,26$ & $56,12 \pm 1,81$ & $471,02 \pm 3,26$ & $484,73 \pm 3,92$ \\
\hline $\mathrm{CV}^{2}, \%$ & \multicolumn{2}{|c|}{3,09} & \multicolumn{2}{|c|}{12,95} & \multicolumn{2}{|r|}{5,82} \\
\hline \multirow[t]{2}{*}{ P value (interaction) } & \multicolumn{2}{|c|}{0,0048} & \multicolumn{2}{|c|}{0,0003} & \multicolumn{2}{|c|}{0,0023} \\
\hline & \multicolumn{2}{|c|}{$\mathrm{THI}$} & \multicolumn{2}{|c|}{$\mathrm{BHGI}$} & \multicolumn{2}{|c|}{ Enthalpy, kJ/kg dry air } \\
\hline Time & $\begin{array}{c}\text { Cooled } \\
\text { ventilation }\end{array}$ & $\begin{array}{c}\text { Natural } \\
\text { ventilation }\end{array}$ & $\begin{array}{c}\text { Cooled } \\
\text { ventilation }\end{array}$ & $\begin{array}{c}\text { Natural } \\
\text { ventilation }\end{array}$ & $\begin{array}{c}\text { Cooled } \\
\text { ventilation }\end{array}$ & $\begin{array}{c}\text { Natural } \\
\text { ventilation }\end{array}$ \\
\hline 07h00 & $74,14 \mathrm{aA}$ & $74,66 \mathrm{aB}$ & $74,82 a A$ & $75,09 a \mathrm{~B}$ & $79,85 a \mathrm{~A}$ & $80,88 a \mathrm{a}$ \\
\hline 09h30 & $75,59 \mathrm{bA}$ & $76,99 \mathrm{bB}$ & $76,86 \mathrm{bA}$ & $77,09 \mathrm{bA}$ & $85,91 \mathrm{bA}$ & $86,71 \mathrm{bB}$ \\
\hline $12 h 00$ & $78,09 \mathrm{cA}$ & $79,12 \mathrm{CA}$ & $79,34 \mathrm{cA}$ & $79,36 \mathrm{cA}$ & $93,07 \mathrm{cA}$ & $94,50 \mathrm{CB}$ \\
\hline $14 \mathrm{~h} 30$ & $78,95 \mathrm{dA}$ & $79,49 \mathrm{~dB}$ & $79,13 \mathrm{CA}$ & $79,06 \mathrm{dA}$ & $94,09 \mathrm{dA}$ & $94,51 \mathrm{CA}$ \\
\hline $17 \mathrm{~h} 00$ & $76,31 \mathrm{eA}$ & $77,01 \mathrm{eB}$ & $77,11 \mathrm{bA}$ & $77,06 \mathrm{bA}$ & $84,64 \mathrm{eA}$ & $85,85 \mathrm{~dB}$ \\
\hline${\text { Average } \pm A S E^{1}}^{\prime}$ & $76,62 \pm 0,49$ & $77,45 \pm 0,50$ & $77,45 \pm 0,48$ & $77,53 \pm 0,45$ & $87,51 \pm 1,55$ & $88,49 \pm 1,53$ \\
\hline $\mathrm{VC}^{2}, \%$ & \multicolumn{2}{|c|}{1,24} & \multicolumn{2}{|c|}{1,27} & \multicolumn{2}{|r|}{2,53} \\
\hline P value (interaction) & \multicolumn{2}{|c|}{0,0001} & \multicolumn{2}{|c|}{0,0002} & \multicolumn{2}{|c|}{0,0038} \\
\hline
\end{tabular}

In the same manner, in other studies,

Tolon \& Nääs (2005), evaluating different ventilation methods (natural, cooled and forced), did not observe effects of fan usage over the environment temperature of the sows' nursery room.

Regarding air relative humidity, there was no effect of the different ventilation methods over this variable; however, there was an effect of the different times of the day. According to Renaudeau et al. (2003), relative humidity values over $85 \%$, when associated with temperatures over the thermal comfort, accentuate the effects of heat stress. In this manner, although the cooled ventilation system utilizes the contact with the humid surface of the plates to the heat change, there is no rise in the humidity level of the environment, which could affect the thermal comfort of the sows due to a high temperature. On the other hand, the advantage of the localized cooling systems usage compared to those whose cooling occurs through increase in the facility humidity, like the fogging system, lies in the maintaining of the absolute humidity in the facility.

The results for radiant thermal load showed that the cooled ventilation system resulted in lower radiant thermal energy on the sow in all times. Corroborating the obtained results, Tolon and Nääs (2005) also observed that in more critical times, regarding the thermal stress for the sows, the cooled ventilation resulted in lower values for the RTL. In the same manner, the values for enthalpy were lower for those sows which received cooled ventilation, except at the time of $14 \mathrm{~h} 30$, due to the cumulative effect of thermal energy; thus, throughout the day, the contribution in radiant thermal energy originated from radiation contributed to rise the enthalpy value in the period, being over the maximum value of 73,8 KJ/kg recommended by Silva (1999).

Considering that, for the evaluated thermal comfort indices, lower values represent better environment conditions; it was verified for the $\mathrm{TH}$ the effect of the adopted ventilation system, observing better indices except for the time of $12 \mathrm{hO0}$. However, the $\mathrm{BHGl}$ obtained values did not point the highest efficiency of the forced ventilation system in the hotter hours of the day. According to Santos et al. (2012) the limit BHGI value for sows is 72 , and therefore the sows subjected to both evaluated ventilation 
systems were in conditions of thermal discomfort.

methods and parturition order for sow weight An interaction among ventilation and daily ration intake was observed (Table 2).

Table 2. Productive and reproductive development of sows from first to third parturition subjected or not to cooled ventilation

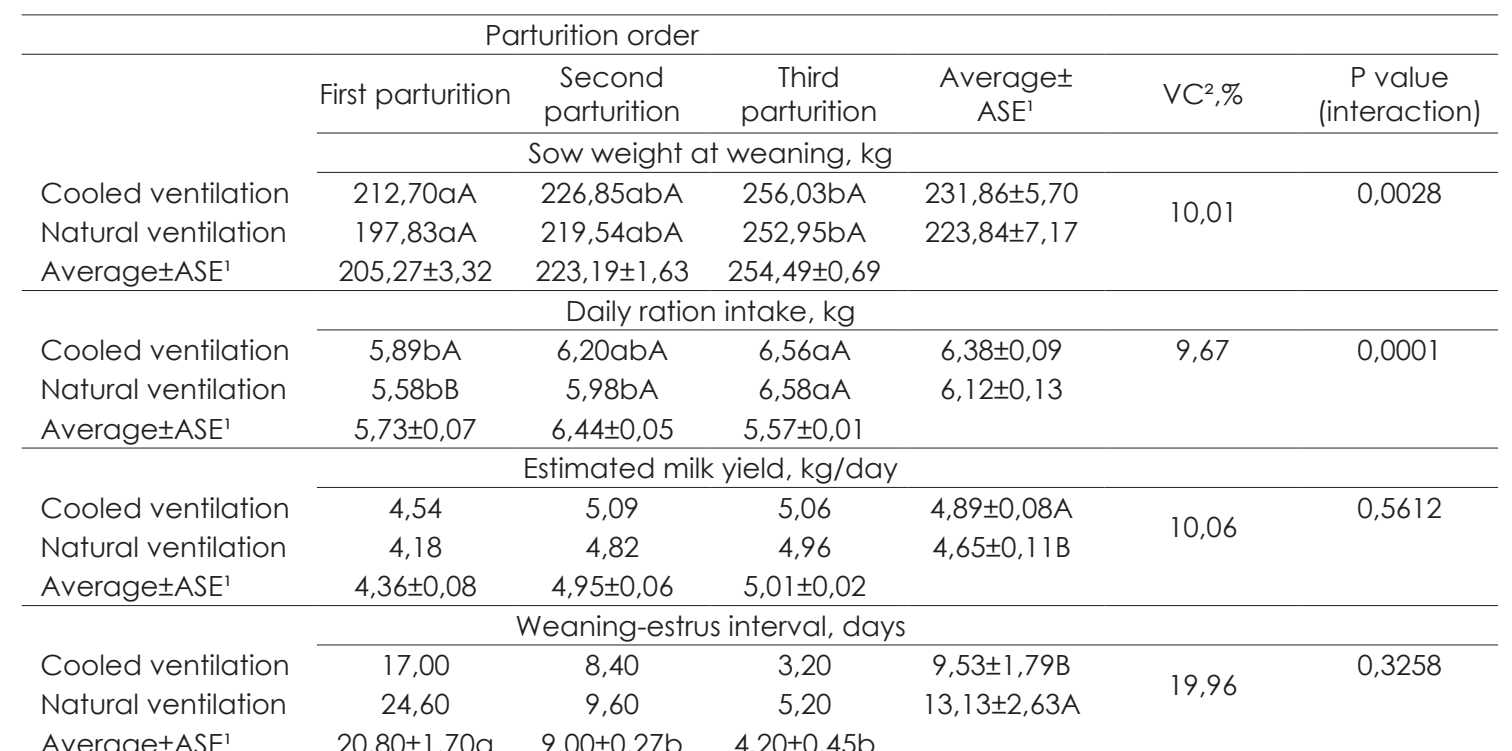

FAverages followed by different letters, lowercase on the line and uppercase on the column, differ among them by Tukey's test at $5 \%$ probability. 'ASE: average standard error. ${ }^{2} \mathrm{VC}$ : variation coefficient.

It was verified that third parturition

sows presented a higher weight at weaning compared to first parturition sows, however not differing from the sows in second parturition. Regarding daily ration intake, third parturition sows presented a higher intake compared to first parturition sows. However, second parturition sows subjected to natural ventilation presented a lower consumption compared to third parturition sows, whilst that difference was not observed for the sows under cooled ventilation. The higher ration intake observed in the first parturition sows which received cooled ventilation compared to those which received natural ventilation is beneficial, since it lowers the mobilization of adipose and muscle tissues, being important to avoid further problems like the second parity syndrome (Patterson et al., 2006).

The effect of parturition order and ventilation methods over the interval weaningestrus was observed, and also only of the ventilation methods over the estimated milk yield. According to the results, the sows which received cooled ventilation presented a higher estimated yield of milk and smaller weaning-estrus interval compared to those under natural ventilation, being also observed a smaller weaning-estrus interval for first parturition sows.
According to Martins et AL. (2008c), thermal stress is more damageable to the primiparous sows, which were shown as more sensible to heath, since they presented a reduced voluntary feeding intake and depended on a greater amount of energy for maintenance, milk production and growth, what might consequently reflect on milk yield and decrease in litter size on second parturition (Prunier \& QUesnel, 2000), resulting in decrease of the reproductive indices.

On the other hand, the negative result of thermal stress over the estimated milk yield can also occur in multiparous, such as was observed by Renaudeau \& Noblet (2001) when they evaluated sows kept in environments with elevated temperature $\left(29^{\circ} \mathrm{C}\right)$ and observed a decline of until $30 \%$ on milk yield, compared to those kept under thermal comfort conditions $\left(20^{\circ} \mathrm{C}\right)$. This way it is possible to infer that the sow capacity in mobilizing body reserves for milk production is conditioned to the thermal environment in which she is kept, and also the interaction of the factors related to the body weight of the piglets (King et al., 1997), number of sucklings (Audist st al., 2000), parturition order, lactation stage, litter size, diet and metabolic status of the sow (Kim et al., 2001).

The prolongation of the first weaning- 
estrus interval might be associated to the loss of body condition during the first lactation, seen that the anorectic effect of thermal stress, notably over primiparous sows, results in a lower intake of food to supply the utilizing of nutrients for growth and milk production (Poleze, 2004). In this sense, since the amount of ingested nutrients during lactation is directly related to hormone secretion, which actuates on the reproductive axis, the not attending of nutritional demands potentially influences the metabolic state and, therefore, the reproductive efficiency of the sow during lactation and after weaning, with the increase of the weaning-estrus interval (Bianchi at al., 2006) or the reduction in the number of piglets born in the subsequent parturition (Mellagi at al., 2013). According to Gourdine et al. (2006) this increase in the weaning-estrus interval is due to the amplification of the puerperal hypothalamic inhibition, more pronounced in primiparous sows.

Regarding the physiological parameters of the sows, excepting rectal temperature, there was an interaction among ventilation methods and hours of the day $(P<0,05)$ by the treatments (Table 3).

Table 3. Physiological parameters of sows from first to third parturition kept in ventilated or not ventilated environments, in function of the time the day

\begin{tabular}{|c|c|c|c|c|c|c|}
\hline \multirow[b]{2}{*}{ Time } & \multicolumn{2}{|c|}{ First parturition females } & \multicolumn{2}{|c|}{ Second parturition females } & \multicolumn{2}{|c|}{ Third parturition females } \\
\hline & $\begin{array}{c}\text { Cooled } \\
\text { ventilation }\end{array}$ & $\begin{array}{c}\text { Natural } \\
\text { ventilation }\end{array}$ & $\begin{array}{c}\text { Cooled } \\
\text { ventilation }\end{array}$ & $\begin{array}{c}\text { Natural } \\
\text { ventilation }\end{array}$ & $\begin{array}{c}\text { Cooled } \\
\text { ventilation }\end{array}$ & $\begin{array}{c}\text { Natural } \\
\text { ventilation }\end{array}$ \\
\hline & \multicolumn{6}{|c|}{ Respiratory rate (movements/minute) } \\
\hline 07h00 & $51,961 \mathrm{aA}$ & $64,490 \mathrm{aA}$ & $37,981 a A$ & $56,226 a A$ & $41,009 a \mathrm{~A}$ & $54,523 a A$ \\
\hline 09h30 & $46,603 a A$ & $64,457 \mathrm{bA}$ & $45,018 a A$ & $60,896 a A$ & $45,183 a \mathrm{~A}$ & $61,727 a A$ \\
\hline $12 \mathrm{~h} 00$ & $57,679 a \mathrm{aB}$ & $94,452 \mathrm{bB}$ & $65,641 \mathrm{aB}$ & $88,075 b B$ & $63,110 \mathrm{aB}$ & $92,383 \mathrm{bB}$ \\
\hline $14 \mathrm{~h} 30$ & $68,059 a B$ & $99,961 \mathrm{bB}$ & $74,568 a \mathrm{~B}$ & $93,862 \mathrm{bB}$ & $74,000 \mathrm{aB}$ & $87,499 \mathrm{bB}$ \\
\hline $17 \mathrm{~h} 00$ & $47,886 a \mathrm{~A}$ & $80,943 \mathrm{bB}$ & $53,547 a A$ & $81,207 \mathrm{bB}$ & $53,504 a A$ & $75,682 \mathrm{bB}$ \\
\hline${\text { Average } \pm \mathrm{ASE}^{\prime}}$ & $54,44 \pm 2,26$ & $80,86 \pm 4,25$ & $55,35 \pm 3,84$ & $76,05 \pm 4,30$ & $55,36 \pm 3,46$ & $74,36 \pm 4,19$ \\
\hline $\mathrm{VC}^{2}, \%$ & \multicolumn{2}{|c|}{27,60} & \multicolumn{2}{|c|}{28,11} & \multicolumn{2}{|c|}{26,58} \\
\hline \multirow[t]{2}{*}{ P value (interaction) } & \multicolumn{2}{|c|}{0,0002} & \multicolumn{2}{|c|}{0,0035} & \multicolumn{2}{|c|}{0,0096} \\
\hline & \multicolumn{6}{|c|}{ Rectal temperature $\left({ }^{\circ} \mathrm{C}\right)$} \\
\hline 07h00 & 38,384 & 37,872 & 38,529 & 38,485 & 38,114 & 38,099 \\
\hline 09h30 & 38,408 & 38,320 & 38,624 & 38,570 & 37,958 & 38,397 \\
\hline $12 \mathrm{~h} 00$ & 38,891 & 38,661 & 39,183 & 38,757 & 38,810 & 38,900 \\
\hline $14 \mathrm{~h} 30$ & 39,184 & 38,746 & 39,513 & 39,445 & 39,310 & 38,763 \\
\hline $17 \mathrm{~h} 00$ & 39,029 & 38,559 & 39,364 & 39,378 & 38,874 & 38,918 \\
\hline Average $\pm A S E^{\prime}$ & $38,78 \pm 0,09$ & $38,43 \pm 0,09$ & $39,04 \pm 0,11$ & $38,93 \pm 0,12$ & $38,61 \pm 0,14$ & $38,61 \pm 0,09$ \\
\hline $\mathrm{VC}^{2}, \%$ & \multicolumn{2}{|c|}{0,99} & \multicolumn{2}{|c|}{1,09} & \multicolumn{2}{|c|}{1,15} \\
\hline \multirow[t]{2}{*}{ P value (interaction) } & \multicolumn{2}{|c|}{0,2862} & \multicolumn{2}{|c|}{0,7526} & \multicolumn{2}{|c|}{0,3593} \\
\hline & \multicolumn{6}{|c|}{ Surface temperature $\left({ }^{\circ} \mathrm{C}\right)$} \\
\hline 07h00 & $30,144 a A$ & $33,376 \mathrm{bA}$ & $30,528 a A$ & $33,657 \mathrm{bA}$ & $31,178 \mathrm{bA}$ & $34,134 \mathrm{bA}$ \\
\hline 09h30 & $32,078 a B$ & $34,450 \mathrm{bB}$ & $32,474 a B$ & $34,873 \mathrm{bB}$ & $33,500 \mathrm{bB}$ & $35,339 \mathrm{bB}$ \\
\hline $12 \mathrm{~h} 00$ & $34,554 \mathrm{aD}$ & $35,822 \mathrm{bc}$ & $35,043 a D$ & $36,364 \mathrm{bc}$ & $35,266 a C$ & $36,547 \mathrm{bc}$ \\
\hline $14 \mathrm{~h} 30$ & $34,693 \mathrm{aD}$ & $35,644 \mathrm{bc}$ & $35,078 \mathrm{aD}$ & $36,366 \mathrm{bc}$ & $35,302 a C$ & $36,261 \mathrm{bc}$ \\
\hline $17 \mathrm{~h} 00$ & $33,179 a C$ & $35,022 \mathrm{bBC}$ & $33,700 \mathrm{aC}$ & $35,683 \mathrm{bc}$ & $33,875 \mathrm{aB}$ & $35,435 \mathrm{bB}$ \\
\hline 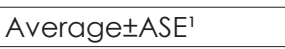 & $32,93 \pm 0,49$ & $34,86 \pm 0,25$ & $33,36 \pm 0,49$ & $35,39 \pm 0,29$ & $33,82 \pm 0,43$ & $35,54 \pm 0,24$ \\
\hline $\mathrm{VC}^{2}, \%$ & \multicolumn{2}{|c|}{5,16} & \multicolumn{2}{|c|}{5,32} & \multicolumn{2}{|c|}{4,54} \\
\hline P value (interaction) & \multicolumn{2}{|c|}{0,0026} & \multicolumn{2}{|c|}{0,0035} & \multicolumn{2}{|c|}{0,0003} \\
\hline
\end{tabular}

For first parturition females, the cooled ventilation system resulted in a lower respiratory rate compared to those which received natural ventilation, in all times, except at 07h00. For second and third parturition females the difference occurred only in the hours after $12 \mathrm{~h} 00$. Concerning the times of the day, it was observed that the females under cooled ventilation presented a higher respiratory rate at $12 \mathrm{~h} 00 \mathrm{e}$ 14h30, independently of the parturition order. For those under natural ventilation the higher rates were observed at 12h00, 14h30 and 17h00.

Considering that in swines the heat dissipation through sweating is practically inexistent (Rodrigues et al., 2010), the increase of the respiratory rate aims the latent thermolysis in 
animals under thermal stress; the lesser increase of this parameter in sows which received cooled ventilation in higher enthalpy hours is advantageous, due to its negative correlation with ration intake.

In this perspective, the answers verified in sows which did not receive cooled ventilation would be an indicative of higher thermal stress to which these animals were being subjected, since the increment of respiratory rate is an efficient physiological mechanism that actuates in the maintaining of thermoregulation (Manno et al., 2006), increasing heat dissipation for the environment. Renaudeau et al. (2003), observed increases from 8 to 20 breaths $/$ minute $/{ }^{\circ} \mathrm{C}$ in sows subjected to temperatures over $28^{\circ} \mathrm{C}$.

In all parturition orders, the respiratory rates of the matrices were higher than those found by Quiniou \& Noblet (1999), being between 26 to 27 movements per minute, although near to those observed by Tolon \& Naas (2005) and Verussa \& Corassa (2013). However, the increase in respiratory rate, for both treatments, was enough for heat dissipation and the maintaining of the rectal temperature of the animals, suggesting that the stress condition through heat was not very severe. The observed values for this variable were revealed to be very near of those found by Lima et al. (2011), with average values of $38,6^{\circ} \mathrm{C}$, being an indicative of normothermia. In counterpart, the rectal temperature answers to changes in internal body heat are slow, since in situations of elevated environmental temperature and no acclimatization, after the sow has exhausted heat loss alternatives through increase in respiratory rate and superficial temperature, an increase in rectal temperature occurs, being this an indicative of late heat stress.

Concerning the superficial temperature, it was noted that the animals subjected to cooled ventilation presented lower values compared to those under natural ventilation, independently of the time of the day and parturition order. The obtained results confirm those presented by Carvalho et al. (2004) who also observed lower superficial temperature near to the withers of sows in termination phase subjected to forced ventilation. The highest superficial temperatures on sows which received natural ventilation are attributed to the increases in peripheral blood circulation as a way of dissipating the body heat and returning homeostasis. Directed cooled ventilation to the hypothalamus of the sow aims not only to lower the superficial temperature of the animal, but also to attenuate physiological modifications in the animals subjected to high temperatures, occasioning a possible reduction in respiratory rate, indicating that animals under this treatment had a greater sensation of thermal comfort.

About the zootechnical development indices of piglets originated from sows subjected to the treatments with and without forced ventilation (Table 4) there was no effect of the ventilation methods and parturition order over the average weight of the piglet at 7 days and daily ration consumption.

An interaction of ventilation methods and parturition order of the matrices over the average weight of the piglet at birth was observed, being the piglets of sows in second and third parturition heavier compared to those from first parturition sows. Evaluating the reproductive parameters of sows in different ages, Souza et al. (2004) observed that young matrices (with age between 7 to 8 months) had lighter piglets, affirming that in this age the animals still demand nutrients for their own growth, since they did not reach a complete body development. A similar effect was noted for the average weight of the piglets at 21 days of age. In this sense, although the weight at birth is a result of primarily gestational factors, weight gain in piglets is a consequence of milk production and lactational behavior of the sow in the nursery (Martins et al. 2008b). Weight gain in piglets has been utilized as one of the indicators of the maternal ability for milk production and, furthermore, since milk production is an important reproductive characteristic in the selection of sows, when the thermal stress is low, the sows present adaptative capacity for milk production, such as the mobilization of body reserves (Clowes et al. 2003). However, as consequence, there may be effects over the puerperium and the preparation for a new estrous cycle, reducing the reproductive indices of the sow, particularly with greater effect in first parturition sows. According to the results, 
Table 4. Development of piglets from sows from first to third parturition subjected or not to cooled ventilation

\begin{tabular}{|c|c|c|c|c|c|c|}
\hline \multicolumn{7}{|c|}{ Parturition order } \\
\hline & First parturition & $\begin{array}{l}\text { Second } \\
\text { parturition }\end{array}$ & $\begin{array}{l}\text { Third } \\
\text { parturition }\end{array}$ & 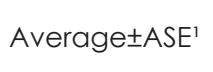 & $\mathrm{VC}^{2}, \%$ & $\begin{array}{c}\text { P value } \\
\text { (interaction) }\end{array}$ \\
\hline \multicolumn{7}{|c|}{ Average piglet weight at birth, $\mathrm{kg}$} \\
\hline Cooled ventilation & $1,31 \mathrm{AA}$ & $1,41 \mathrm{bA}$ & $1,49 \mathrm{bA}$ & $1,40 \pm 0,02$ & 7,57 & 0,0002 \\
\hline Natural ventilation & $1,25 a \mathrm{~A}$ & $1,43 \mathrm{bA}$ & $1,53 \mathrm{bA}$ & $1,40 \pm 0,03$ & & \\
\hline 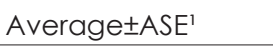 & $1,28 \pm 0,01$ & $1,42 \pm 0,01$ & $1,51 \pm 0,01$ & & & \\
\hline \multicolumn{7}{|c|}{ Average piglet weight at 7 days, $\mathrm{kg}$} \\
\hline Cooled ventilation & 2,18 & 3,08 & 2,76 & $2,67 \pm 0,12$ & 18,87 & 0,5896 \\
\hline Natural ventilation & 2,17 & 3,02 & 2,83 & $2,68 \pm 0,11$ & & \\
\hline 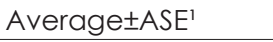 & $2,17 \pm 0,01$ & $3,05 \pm 0,01$ & $2,79 \pm 0,01$ & & & \\
\hline \multicolumn{7}{|c|}{ Average piglet weight at 21 days, $\mathrm{kg}$} \\
\hline Cooled ventilation & $4,79 \mathrm{bA}$ & $6,16 a A$ & $5,78 a A$ & $5,58 \pm 0,18$ & 10,96 & 0,0035 \\
\hline Natural ventilation & $4,84 \mathrm{bA}$ & $5,29 a A$ & $5,76 a A$ & $5,29 \pm 0,12$ & & \\
\hline${\text { Average } \pm A S E^{\prime}}^{\prime}$ & $4,81 \pm 0,01$ & $5,72 \pm 0,19$ & $5,77 \pm 0,01$ & & & \\
\hline \multicolumn{7}{|c|}{ Daily ration intake, g/animal } \\
\hline Cooled ventilation & 36,16 & 33,87 & 33,43 & $34,48 \pm 0,38$ & 14,01 & 0,1688 \\
\hline Natural ventilation & 28,25 & 34,70 & 35,86 & $32,94 \pm 1,06$ & & \\
\hline Average \pm ASE $^{1}$ & $32,20 \pm 1,77$ & $34,28 \pm 0,19$ & $34,64 \pm 0,54$ & & & \\
\hline
\end{tabular}

error. ${ }^{2} \mathrm{VC}$ variation coefficient.

cooled ventilation, particularly in primiparous, promotes the increase of ration consumption, being favorable for tissue maintenance of the sows and in the reduction of the second parity syndrome.

\section{Conclusions}

1. The cooled ventilation climatization system results in reduction of radiant thermal load and in a better index of thermal comfort throughout the day.

2. From $09 \mathrm{~h} 30$ to $17 \mathrm{~h} 00$, sows under cooled ventilation presented lower respiratory rate compared to those under natural ventilation.

3. Cooled ventilation results in higher ration consumption in first parturition sows, compared to natural ventilation.

\section{Acknowledgments}

To the Xerez Farm, for the support and contribution in the accomplishment of this experiment.

\section{References}

Audist, D.E., Carlson, D., Morrish, L., Wakeford, C.M., King, R.H. 2000. The influence of suckling interval on milk production of sows. Journal of Animal Science, v.78, n.8, p.2026-2031.

Barbari, M., Conti, L. 2009. Use of different cooling systems by pregnant sows in experimental pen. Biosystems Engineering, v. 103, n. 2, p. 239-244.

Bortolozzo, F.P., Kummer, A.B.H.P., Lesskiu,
P.E.; Wentz, I. 2011. Estratégias de redução do catabolismo lactacional manejando a ambiência na maternidade. Disponível em: <http://suinotec.com.br/arquivos_artigos/ Bortolozzo_2010_Estrategias_de_reducao_do_ catabolismo_lactacional_manejando.pdf $>$. Acesso 02/06/2013.

Carvalho, L.E., Oliveira, S.M.P, Turco, S.H.N. 2004. Utilização da Nebulização e Ventilação Forçada sobre o Desempenho e a Temperatura da pele de Suínos na Fase de Terminação. Revista Brasileira de Zootecnia, v.33, n.6, p.1486-1491.

Close, W.H.; Cole, D.J.A. Nutrition of sows and boars. 2001. British Library cataloguing in publication data. Nottingham: Nottingham University Press, 378p

Clowes, E.J., Aherne, F.X., Schaefer, A.L., Foxcroft, G.R., Baracos, V.E. 2003. Parturition body size and body protein loss during lactation influence performance during lactation and ovarian function at weaning in first-parity sows. Journal of Animal Science, v.81, n.6, p.1517-1528.

Eissen, J.J., Kanis, E., Kemp, B. 2000. Sow factors affecting voluntary feed intake during lactation. Livestock Production Science, v.64, n.2-3, p.147165.

Gourdine, J.L., Bidanel, J.P., Noblet, J. 1999. Effects of breed and season on performance of lactating sows in a tropical humid climate. Journal of Animal Science, v.77, n.6, p.1513-1522.

Kim, S.W., Páscoa, R.A., Hurley, W.L. 2001. The regression of unsuckled mammary glands during lactation in sows: the influence of lactation stage, dietary nutrients, and litter size. Journal of Animal 
Science, v.79,n.10, p.2659-2668.

King, R.H., Mullan, B.P., Dunshea, F.R., Dove, H. 1997. The influence of piglet body weight on milk production of sows. Livestock Production Science, v.47,n.2, p.169-174.

Manno, M.C., Oliveira, R.F.M., Donzele, J.L., Pereira, W.O., Vaz, R.G.M.V, Silva, B.A.N., Saraiva, E.P., Lima, K.R.S. 2006. Efeitos da temperatura ambiente sobre o desempenho de suínos dos 30 aos 60kg. Revista Brasileira de Zootecnia, v.35, n.2, p.471-477.

Martins, T.D.D.; Costa, A.N. 2008a. Desempenho e comportamento de fêmeas suínas lactantes criadas em climas tropicais. Archivos de Zootecnia, v. 57, p. 78.

Martins, T.D.D., Costa, A.N., Silva, J.H.V., Valença, R.M.B., Ludke, J.V. 2008b. Postura e comportamento lactacional de matrizes suínas mantidas sob condições de temperatura ambiente elevada. Biotemas, v.21, n.4, p.137145.

Martins, T.D.D., Costa, A.N, Silva, J.H.V. 2008c. Respostas termorreguladoras de matrizes suínas híbridas em lactação, mantidas em ambiente quente. Ciência e Agrotecnologia, v.32, n.3, p.961-968.

Mellagi, A.P.G.; Panzardi, A.; Bierhals, T.; Gheller, N.B.; Bernardi, M.L.; Wentz, I.; Bortolozzo, F.P. 2013. Efeito da ordem de parto e da perda de peso durante a lactação no desempenho reprodutivo subsequente de matrizes suínas. Arquivo Brasileiro de Medicina Veterinária e Zootecnia, v.65, n.3, p.891-825.

Moreira, R.F. 2003. Desenvolvimento de sistemas de resfriamento e aquecimento de pisos de maternidades suinícolas visando o conforto térmico e desempenho de matrizes e leitões. (Tese de Doutorado) - Universidade Federal de Viçosa.

Mueller, E.N., Bergmann, L.K., Anciuti, A.N., Tillman, M.T., Nobre, M.O. Estudo da diferença das temperaturas retal e do canal auditivo de acordo com a conformação acústica da concha acústica de cães. Semina: Ciências Agrárias, v.33, p.1907-1910, 2012.

Patterson J., Zimmerman, P., Dyck, M., Foxcroft, G. Effect of skip-a-heat breeding on subsequent reproductive performance in 1st parity sows. Advances in Pork Production. v. 17, Abstract 24, 2006.

Prunier, A., Quesnel, H. 2000. Influence of the nutritional status on ovarian development in female pigs. Animal Reproduction Science, v.6061, p.185-197.
Quiniou, N.; Noblet, J. 1999. Influence of high ambient temperatures on performance of multiparous lactating sows. Journal of Animal Science, v.77, n.8, p.2124-2134.

Renaudeau, D.; Noblet, J. 2001. Effects of exposure to high ambient temperature and dietary protein level on sow milk production and performance of piglets. Journal of Animal Science, v.79, n.6, p.1540-1548.

Renaudeau, D.; Noblet, J.; Dourmad, J.Y. 2003. Effect of ambient temperature on mammary gland metabolism in lactating sows. Journal of Animal Science, v.81, p.217-231.

Rodrigues, N.E.B.; Zangeronimo, M.G.; Fialho, E.T. 2010. Adaptações fisiológicas de suínos sob estresse térmico. Revista Eletrônica Nutritime, v.7, p.1197-1211.

Rozeboom K.J., Troedsson M.H.T., Hodson H.H., Shurson G.C.; Crabo B.G. 2000. The importance of seminal plasma on the fertility of subsequent artificial inseminations in swine. Journal of Animal Science, v.78, p443-448.

Santos, J.H.T., Tinoco, I.F.F., Costa, C.A. 2012. Avaliação Diferentes Sistemas de Ventilação em Terminação de Suínos, para as condições do Centro-Oeste Brasileiro. Revista Engenharia na Agricultura, v. 20, n. 3.

Silva, I.J.O. 1999. Sistemas naturais e artificiais do controle do ambiente - climatização. (Ed.) Ambiência e qualidade na produção industrial de suínos. Piracicaba: Fundação de Estudos Agrários Luiz de Queiroz. p.81-101.

Spencer, J.D., Boyd, R.D., Carera, R., Allee, G.L. 2003. Early weaning to reduce tissue mobilization in lactating sows and milk supplementation to enhance pigs weaning weight during extreme heat stress. Journal of Animal Science, v.81, p. 2041-2052.

Tolon, Y.B., Nããs, I.A. 2005. Avaliação de tipos de ventilação em maternidade de suínos. Engenharia Agrícola, v.25 n.3, p.565-574.

Verussa, G.H., Corassa, A. 2013. Aspectos bioclimáticos de porcas em lactação na região de transição cerrado-amazônia. Revista Eletrônica Nutritime, v.10, n.6, p.2895-2908. 